\title{
Pengaruh Kemiringan Benda Kerja dan Kecepatan Pemakanan terhadapGetaran Mesin Frais Universal Knuth UFM 2
}

\author{
Romiyadi $^{1}$ \\ ${ }^{1}$ Program Studi Perawatan dan Perbaikan Mesin, Politeknik Kampar \\ Jl. Tengku Muhammad (KM.2), Bangkinang, 28461 \\ ${ }^{1}$ Email : romiyadi.nawir@gmail.com
}

\begin{abstract}
In milling process with slope of workpiece, the milling process requires more energy from milling machine. The greater the slope of workpiece estimated to be the greater energyrequired by the milling machine. Therefore, the machining vibration that occurs was estimated to be very big. This study aimed to determine influence theslope of workpiece to machining vibration in milling machine with variations of feeding. This study used Milling Machine Knuth Universal UFM 2 with vertical milling approach. The slope of workpiece used was $30^{\circ}$, $45^{\circ}$ and $60^{\circ}$.The machining process parameters varied was feeding while depth of cut and spindle speed were constant. The study results show that the greater the slope of work piece, the greater the machining vibration on the up milling process and the down milling processes for all slope of work piece. Similarly the influence of feeding to machining vibration in milling process. The study results show that the change of feeding will give a positive impact to machining vibration on the up milling process and the down milling processes. For same the slope of workpiece and feeding the machining vibration on the down milling process is greater than the up milling process.
\end{abstract}

Keywords :Machining vibration, slope of work piece, feed, up milling, down milling

\section{PENDAHULUAN}

Proses produksi pembuatan suatu produk manufaktur yang ada didunia hampir seluruhnya memerlukan proses pemesinan [5]. Proses pemesinan adalah suatu proses manufaktur dimana proses utamanya adalah melepaskan atau menghilangkan sebagian material dari suatu bahan dasar yang dapat berupa blok atau silinder pejal sehingga memenuhi bentuk dan kualitas yang diinginkan. Selain itu, proses pemesinan ini merupakan salah satu proses manufaktur yang kompleks karena harus mempertimbangkan banyak faktor agar produk yang dihasilkan sesuai dengan spesifikasi kualitas yang ditetapkan.

Proses pemesinan frais (milling)merupakan salah satu proses pemesinan yang banyak digunakan untuk pembuatan komponen [2]. Proses pemesinan frais sering digunakan untuk membuat komponen yang mempunyai fitur berupa suatu profil dan juga trajectory yang kompleks. Sebagai contoh, proses pemesinan frais sering digunakan dalam pembuatan cetakan (mould) untuk membuat produk-produk dari plastik. Pengoperasian mesin frais tidak terlepas dari parameter proses pemesinan. Parameter proses pemesinan terdiri dari kecepatan putaran spindel (spindle speed), kecepatan potong (cutting speed), kedalaman potong (dept of cut), kecepatan pemakanan (feed), gerak makan pergigi (chip load) dan waktu pemotongan. Besar kecepatan putaran spindel, kecepatan pemakanan dan kedalaman potong pada mesin milling dapat dipilih sesuai dengan yang tertera pada mesin frais. Pengaturan besar kecepatan putar dan kedalaman potong tergantung dari pengetahuan dan pengalaman dalam mengoperasikan mesin perkakas [6].

Perubahan kecepatan putaran spindel, kecepatan pemakanan, dan kedalaman potong pada proses frais akan menyebabkan terjadinya perubahan kekasaran permukaan produk yang dihasilkan [2]. Kekasaran produk yang terjadi diakibatkan oleh adanya getaran yang timbul pada mesin pada saat mesin itu beroperasi [6]. Semakin besar nilai amplitudo getaran, semakin besar pula nilai kekakasaran permukaan pada produk yang dihasilkan dan begitu juga sebaliknya [3].

Getaran pemesinan merupakan parameter pemotongan yang tidak dapat dikontrol secara bebas, sebab keberadaannya akan selalu timbul selama proses pemesinan berlangsung (Muas, 2008). Menurut Kalpakjian [7], getaran pemesinan (machining vibration) merupakan getaran yang timbul selama proses pemotongan berlangsung dan disebabkan sedikitnya oleh dua hal yaitu getaran yang timbul akibat gaya potong dan getaran akibat eksitasi pribadi . Dampak getaran pemesinan yang muncul pada mesin fraissangat besar pengaruhnya. Selain berdampak pada kekasaran permukaan produk yang dihasilkan, getaran yang tinggi pada mesin frais juga bisa menyebabkan keausan pahat dan umur mesin menjadi lebih pendek [4].

Pada proses frais dengan pemakanan menyudut seperti pada proses pembuatan $V$-Block, proses pemakanan yang dilakukan membutuhkan energi atau power yang sangat besar dari mesin frais. Semakin besar sudut pemakanan diperkirakan semakin besar pula energi yang dikeluarkan oleh mesin frais tersebut. Oleh karena itu getaran yang 
timbul dari pemakanan menyudut pada mesin frais kemungkinan sangat besar.

Getaran pemesinan merupakan parameter pemotongan yang tidak dapat dikontrol secara bebas, sebab keberadaannya akan selalu timbul selama proses pemesinan berlangsung [3]. Menurut Kalpakjian [7], getaran pemesinan (machining vibration) merupakan getaran yang timbul selama proses pemotongan berlangsung dan disebabkan sedikitnya oleh dua hal yaitu getaran yang timbul akibat gaya potong dan getaran akibat eksitasi pribadi .

Mesin perkakas dirancang dengan menggunakan konsep high speed dan high power. Konsep ini menuntut rancangan mesin perkakas harus memiliki kekakuan yang tinggi. Kekakuan tinggi biasanya diikuti dengan volume rancangan mesin perkakas yang besar. Hal ini sangat merugikan karena volume rancangan yang besar membutuhkan jumlah material yang besar juga. Untuk itu dirancang sistem kekakuan mesin perkakas yang lebih kaku dengan menggunakan ribbing. Sehingga getaran mesin perkakas dapat diredam oleh mesin perkakas yang memiliki kekakuan tinggi tapi volumenya tidak besar. Mesin perkakas dirancang dengan memperhatikan aspek kekakuan statik dan dinamik [4]. Misalnya ditinjau dari aspek kekakuan dinamik yaitu deformasi relatif antara pahat dengan benda kerja dan getaran yang timbul karena adanya gaya eksitasi (getaran paksa), gaya eksitasi sesaat (getaran bebas) dan getaran karena adanya getaran eksitasi diri.

Dampak getaran yang muncul pada mesin perkakas sangat besar pengaruhnya. Itu dapat dilihat pada produk yang dihasilkan, umur pahat dan umur mesin perkakas yang digunakan. Getaran yang tinggi akan mengakibatkan kualitas benda kerja menjadi kurang bagus, umur pahat menjadi lebih rendah dan mesin tidak tahan lama. Getaran mesin perkakas berpengaruh terhadap mesin perkakas, kondisi pemotongan, getaran benda kerja dan umur pahat. Pengaruh getaran pada kondisi pemotongan dapat dilihat dari perubahan geram dimana akibat perubahan gaya pemotongan juga menghasilkan perubahan geram [4].

Dalam membicarakan getaran kita harus mengetahui batasan-batasan level getaran yang menunjukkan kondisi suatu mesin, apakah mesin tersebut masih baik (layak beroperasi) ataukah mesin tersebut sudah mengalami suatu masalah sehingga memerlukan perbaikan. Gambar 1 menunjukkan level getaran berdasarkan ISO 10816 terhadap mesin yang diklasifikasikan berdasarkan daya atau powermesin.

\section{VIBRATION SEVERITY PER ISO 10816}

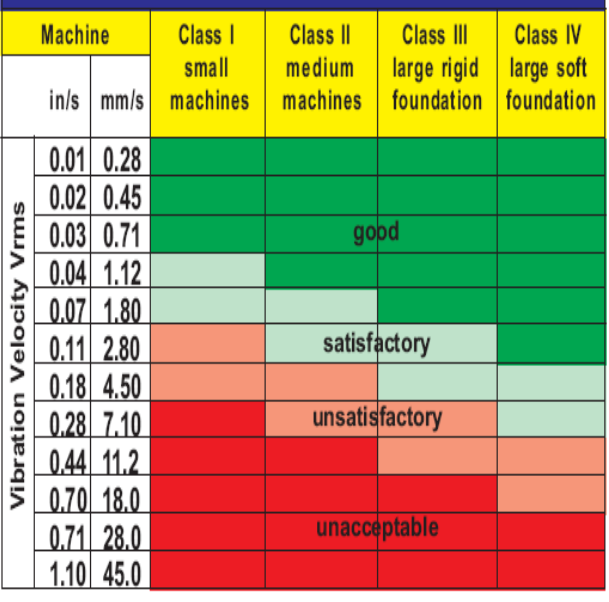

Class I. Small-sized machines (powered from 0 to $15 \mathrm{KW}$ )

Class II. Medium-sized machines (powered from 15 to 75 KW)

Class III. Large-sized machines (powered > $75 \mathrm{KW}$ ) mounted on "Rigid Support" structures and foundations Class IV. Large-sized machines (powered $>75 \mathrm{~kW}$ ) mounted on "Flexible Support" structures

Gambar 1. Diagram level getaran mesin per ISO 10816

(Sumber : Phase II machine tools, 2008)

\section{METODE PENELITIAN}

Proses pengambilan data pada penelitian ini dilaksanakan di Workshop Politeknik Kampar. Pada penelitian ini dilakukan proses frais pemakanan menyudut dengan kemiringan benda kerja $30^{\circ}, 45^{\circ}$ dan $60^{\circ}$. Parameter proses pemesinan yang divariasikan adalah kecepatan pemakanan, sedangkan parameter lainnya yaitu kecepatan putaran spindel dan kedalaman potong dibuat konstan.

Fasilitas utama yang digunakan adalah Mesin Frais Universal Knuth UFM 2 dengan pendekatan mesin frais vertikal (gambar 2), CutterEnd Mill material HSS dengan diameter 16 mmdan jumlah gigi 4 (gambar 3) serta Digital Vibration Tester Meter Phase II DVM 1000 (gambar 4).

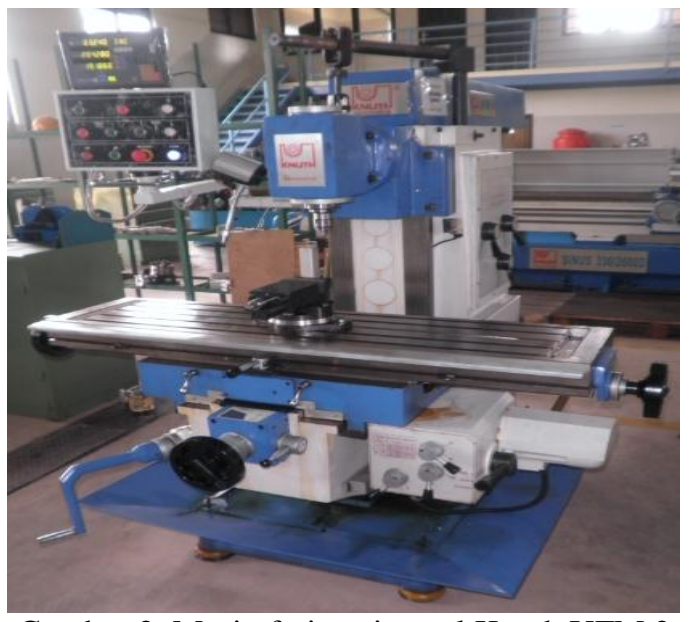

Gambar 2. Mesin frais universal Knuth UFM 2 


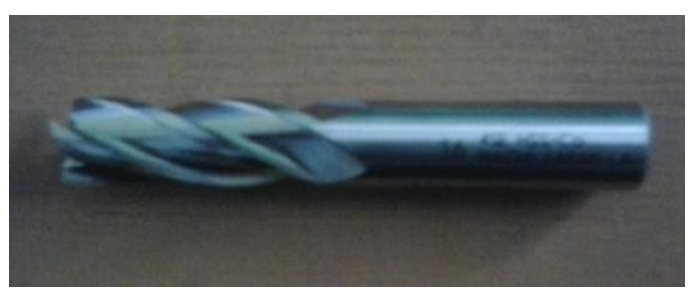

Gambar 3. Cutter endmil HSS

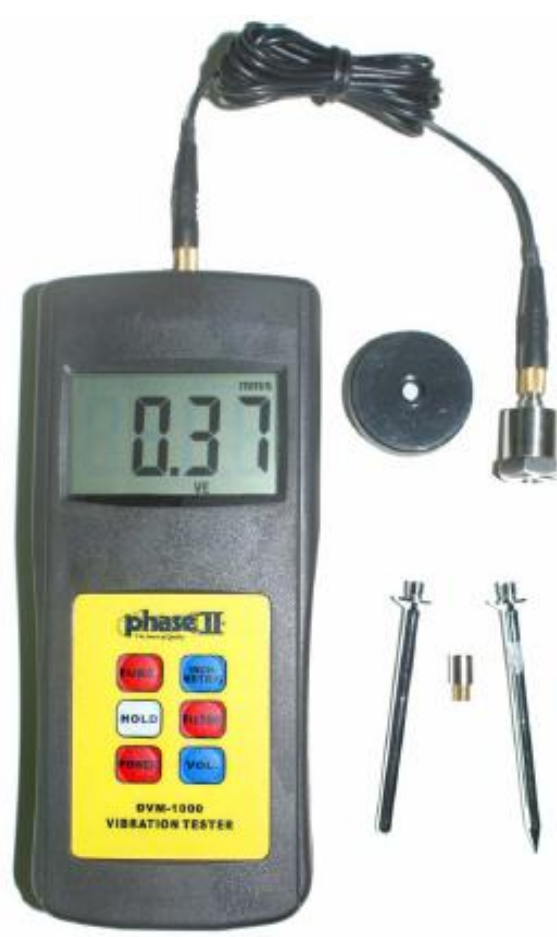

Gambar 4. Digital vibration tester meter phase II DVM 1000

(Sumber : Phase II machine tools, 2008)

Metode penelitian yang digunakan pada penelitian ini dapat dilihat pada gambar 5 dibawah ini.

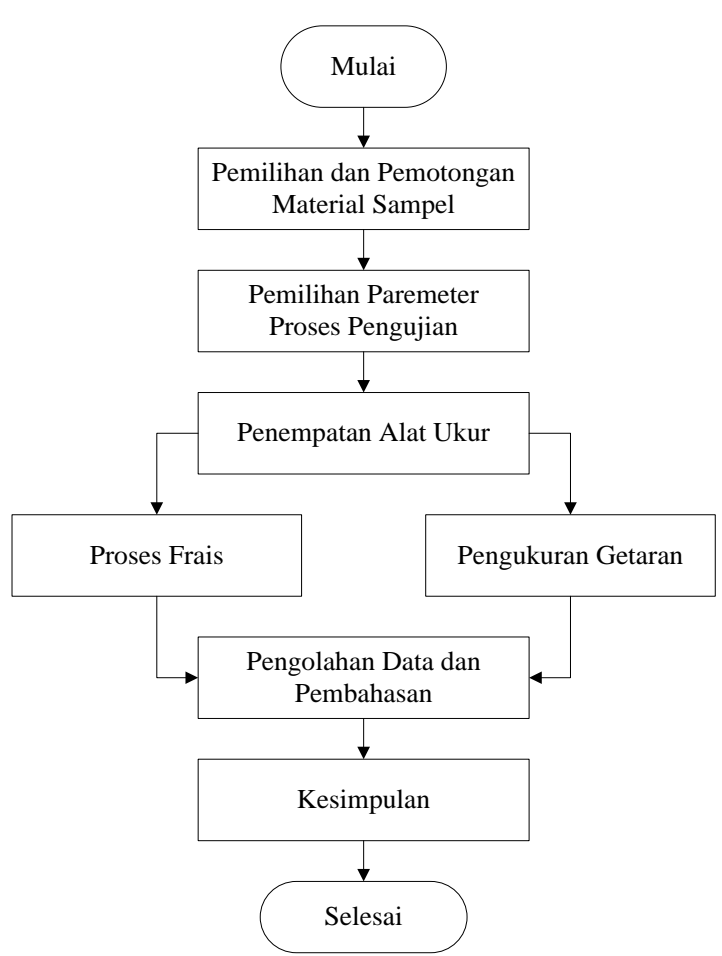

Gambar 5. Diagram alir penelitian

\section{Pemilihan dan Pemotongan Material Sampel}

Material yang digunakan dalam penelitian ini adalah Material Baja Lunak (Mild Steel) jenis Plat Strip. Material berbentuk persegi dengan ukuran 65 $\mathrm{mm}$ x $15 \mathrm{~mm}$. Material sampel tersebut dipotong sepanjang $100 \mathrm{~mm}$. Material sampel ditunjukkan pada gambar 6 .

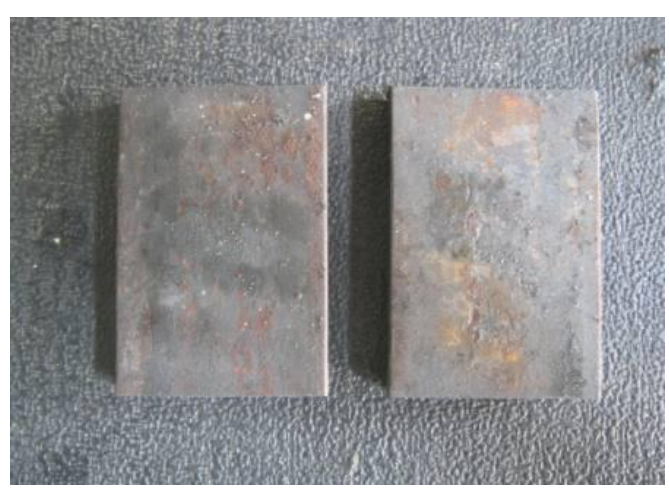

Gambar 6. Material sampel

\section{- Pemilihan Parameter Pengujian}

Setelah material sampel tersedia, maka proses selanjutnya adalah memilih parameter apa saja yang digunakan dalam proses pengujian. Parameter getaran yang digunakan pada penelitian ini adalah amplitudo kecepatan getaran (vibration velocity). Sedangkan paremeter proses pemesinan yang digunakan adalah kedalaman potong (depth of cut), kecepatan putaran spindel (spindle speed) dan 
kecepatan pemakanan (feed) dengan sudut kemiringan benda kerja adalah $30^{\circ}, 45^{\circ}$ dan $60^{\circ}$.

Parameter kecepatan pemakanan dibuat bervariasi sedangkan parameter lainnya yaitu kecepatan putaran spindel dan kedalaman potong dibuat konstan. Nilai kecepatan pemakanan yang digunakan adalah $45 \mathrm{~mm} / \mathrm{min}, 69 \mathrm{~mm} / \mathrm{min}, 108$ $\mathrm{mm} / \mathrm{min}, 168 \mathrm{~mm} / \mathrm{min}$ dan $233 \mathrm{~mm} / \mathrm{min}$. Sedangkan nilai kecepatan putaran spindel yang digunakan adalah $388 \mathrm{rpm}$ dan nilai kedalaman potong yang digunakan adalah $0.5 \mathrm{~mm}$. Sudut kemiringan benda kerja yang digunakan adalah $30^{\circ}, 45^{\circ}$ dan $60^{\circ}$.

\section{- Pengukuran Getaran}

Pengukuran dilakukan dengan bantuan 2 orang operator dimana salah satunya bertugas mencatat nilai yang tertera pada alat ukur. Pengukuran getaran dilakukan sepanjang benda kerja dan pencatatan dimulai saat nilai kecepatan getaran sudah stabil. Pengukuran dilakukan 2 kali pada masin-masing parameter kecepatan pemakanan baik untuk proses up milling maupun untuk proses down milling.

- Penempatan Alat Ukur

Alat ukur yang digunakan adalah Digital
Vibration Tester Meter Phase II DVM 1000. Pada saat pengukuran, alat ukur tersebut ditempatkan pada benda kerja. Ketelitian alat ukur 0,01 mm/s[8].

\section{- Proses Frais}

Proses frais yang digunakan pengujian ini adalah proses frais jari (end milling) dengan menggunakan metode up milling (putaran spindel berlawanan dengan pergerakan meja) dan down milling (putaran spindel searah dengan pergerakan meja).

\section{HASIL DAN PEMBAHASAN}

\section{A. Pengaruh Kemiringan Benda Kerja dan Kecepatan Pemakanan Terhadap Getaran Mesin Frais}

Pengukuran getaran dilakukan pada proses frais menggunakan metode up milling dan down milling. Pengukuran getaran ini dilakukan sebanyak 2 kali untuk masing-masing kecepatan pemakanan dan nilai yang diambil adalah nilai rata-rata. Hasil pengukuran dapat dilihat pada tabel 1 dibawah ini. 
Tabel 1. Hasil pengukuran kemiringan benda kerja dan kecepatan pemakanan terhadap getaran mesin frais

\begin{tabular}{|c|c|c|c|c|c|c|c|c|c|c|}
\hline \multirow[b]{2}{*}{ No } & \multirow[b]{2}{*}{$\begin{array}{l}\boldsymbol{\theta} \\
\left(^{\mathbf{0}}\right)\end{array}$} & \multirow[b]{2}{*}{$\begin{array}{c}\mathrm{N} \\
\text { (rpm } \\
\text { ) }\end{array}$} & \multirow[b]{2}{*}{$\begin{array}{c}\text { Vf } \\
(\mathrm{m} / \mathrm{mnt} \\
)\end{array}$} & \multirow[b]{2}{*}{$\begin{array}{l}\text { DOC } \\
(\mathbf{m m})\end{array}$} & \multicolumn{3}{|c|}{ Up Milling } & \multicolumn{3}{|c|}{ Down Milling } \\
\hline & & & & & $\begin{array}{c}\mathrm{V}_{1} \\
(\mathrm{~mm} / \mathrm{s} \\
)\end{array}$ & $\begin{array}{c}\mathrm{V}_{2} \\
(\mathrm{~mm} / \mathrm{s} \\
)\end{array}$ & $\begin{array}{c}\text { Vrata-rata } \\
(\mathrm{mm} / \mathrm{s})\end{array}$ & $\begin{array}{c}\mathrm{V}_{1} \\
(\mathrm{~mm} / \mathrm{s} \\
)\end{array}$ & $\begin{array}{c}\mathrm{V}_{2} \\
(\mathrm{~mm} / \mathrm{s} \\
)\end{array}$ & $\begin{array}{c}\text { Vrata-rat } \\
\mathbf{a} \\
(\mathrm{mm} / \mathrm{s})\end{array}$ \\
\hline 1 & 30 & 388 & 45 & 0,50 & 0,59 & 0,57 & 0,58 & 0,91 & 0,88 & 0,90 \\
\hline 2 & 30 & 388 & 69 & 0,50 & 0,59 & 0,59 & 0,59 & 0,99 & 1,02 & 1,01 \\
\hline 3 & 30 & 388 & 108 & 0,50 & 0,61 & 0,63 & 0,62 & 1,08 & 1,10 & 1,09 \\
\hline 4 & 30 & 388 & 168 & 0,50 & 0,69 & 0,70 & 0,70 & 1,11 & 1,12 & 1,12 \\
\hline 5 & 30 & 388 & 233 & 0,50 & 0,73 & 0,73 & 0,73 & 1,17 & 1,16 & 1,17 \\
\hline \multirow[b]{2}{*}{ No } & \multirow[b]{2}{*}{$\begin{array}{l}\boldsymbol{\theta} \\
\left(^{\mathbf{0}}\right)\end{array}$} & \multirow[b]{2}{*}{$\begin{array}{c}\mathrm{N} \\
\text { (rpm } \\
\text { ) }\end{array}$} & \multirow[b]{2}{*}{$\begin{array}{c}\text { Vf } \\
(\mathbf{m} / \mathbf{m n t} \\
)\end{array}$} & \multirow[b]{2}{*}{$\begin{array}{l}\text { DOC } \\
(\mathbf{m m})\end{array}$} & \multicolumn{3}{|c|}{ Up Milling } & \multicolumn{3}{|c|}{ Down Milling } \\
\hline & & & & & $\begin{array}{c}\mathrm{V}_{1} \\
(\mathrm{~mm} / \mathrm{s} \\
)\end{array}$ & $\begin{array}{c}\mathrm{V}_{2} \\
(\mathrm{~mm} / \mathrm{s} \\
)\end{array}$ & $\begin{array}{c}\text { Vrata-rata } \\
(\mathbf{m m} / \mathbf{s})\end{array}$ & $\begin{array}{c}\mathrm{V}_{1} \\
(\mathrm{~mm} / \mathrm{s} \\
)\end{array}$ & $\begin{array}{c}\mathrm{V}_{2} \\
(\mathrm{~mm} / \mathrm{s} \\
)\end{array}$ & $\begin{array}{c}\text { Vrata-rata } \\
(\mathbf{m m} / \mathbf{s})\end{array}$ \\
\hline 1 & 45 & 388 & 45 & 0,50 & 0,65 & 0,64 & 0,65 & 0,92 & 0,90 & 0,91 \\
\hline 2 & 45 & 388 & 69 & 0,50 & 0,65 & 0,66 & 0,66 & 1,03 & 1,03 & 1,03 \\
\hline 3 & 45 & 388 & 108 & 0,50 & 0,67 & 0,67 & 0,67 & 1,20 & 1,19 & 1,20 \\
\hline 4 & 45 & 388 & 168 & 0,50 & 0,71 & 0,71 & 0,71 & 1,31 & 1,34 & 1,33 \\
\hline 5 & 45 & 388 & 233 & 0,50 & 0,75 & 0,76 & 0,76 & 1,39 & 1,41 & 1,40 \\
\hline \multirow[b]{2}{*}{ No } & \multirow[b]{2}{*}{$\begin{array}{l}\boldsymbol{\theta} \\
\left(^{\mathbf{0}}\right)\end{array}$} & \multirow[b]{2}{*}{$\begin{array}{c}\mathrm{N} \\
\text { (rpm } \\
\text { ) }\end{array}$} & \multirow[b]{2}{*}{$\begin{array}{c}\text { Vff } \\
(\mathrm{m} / \mathrm{mnt} \\
)\end{array}$} & \multirow[b]{2}{*}{$\begin{array}{l}\text { DOC } \\
(\mathrm{mm})\end{array}$} & \multicolumn{3}{|c|}{ Up Milling } & \multicolumn{3}{|c|}{ " Down Milling } \\
\hline & & & & & $\begin{array}{c}\mathrm{V}_{1} \\
(\mathrm{~mm} / \mathrm{s} \\
)\end{array}$ & $\begin{array}{c}\mathrm{V}_{2} \\
(\mathrm{~mm} / \mathrm{s} \\
)\end{array}$ & $\begin{array}{c}\text { Vrata-rata } \\
(\mathrm{mm} / \mathrm{s})\end{array}$ & $\begin{array}{c}\mathrm{V}_{1} \\
(\mathrm{~mm} / \mathrm{s} \\
)\end{array}$ & $\begin{array}{c}\mathrm{V}_{2} \\
(\mathrm{~mm} / \mathrm{s} \\
)\end{array}$ & $\begin{array}{c}\text { Vrata-rata } \\
(\mathrm{mm} / \mathrm{s})\end{array}$ \\
\hline 1 & 60 & 388 & 45 & 0,50 & 0,69 & 0,66 & 0,68 & 1,07 & 1,06 & 1,07 \\
\hline 2 & 60 & 388 & 69 & 0,50 & 0,77 & 0,75 & 0,76 & 1,23 & 1,22 & 1,23 \\
\hline 3 & 60 & 388 & 108 & 0,50 & 0,85 & 0,86 & 0,86 & 1,49 & 1,49 & 1,49 \\
\hline 4 & 60 & 388 & 168 & 0,50 & 1,01 & 1,00 & 1,01 & 1,71 & 1,74 & 1,73 \\
\hline 5 & 60 & 388 & 233 & 0,50 & 1,14 & 1,17 & 1,16 & 1,91 & 1,89 & 1,90 \\
\hline
\end{tabular}

Keterangan :

- $\Theta=$ Sudut Kemiringan Benda Kerja

- $\mathrm{N} \quad=$ Kecepatan Putaran Spindel

- $\mathrm{Vf}=$ Kecepatan Pemakanan

- $\quad$ DOC $=$ Kedalaman Potong

- $\mathrm{V}_{1}=$ Kecepatan Getaran Pengujian ke 1

- $\mathrm{V}_{2}=$ Kecepatan Getaran Pengujian ke 2

Hasil pengukuran yang terlihat pada tabel 1 menunjukkan bahwa semakin besar sudut kemiringan benda kerja, semakin besar pula getaran mesin frais yang terjadi baik pada proses up milling maupun pada proses down milling. Begitu pula dengan pengaruh perubahan kecepatan pemakanan terhadap getaran mesin frais. Hasil pengukuran menunjukkan bahwa pada sudut kemiringan bendakerja $30^{\circ}, 45^{\circ}$ maupun $60^{\circ}$, perubahan kecepatan pemakanan memberikan pengaruh positif terhadap getaran mesin frais. Hasil pengukuran juga menunjukkan bahwa getaran mesin frais yang terjadi pada proses down milling lebih tinggi dibandingan dengan getaran pada proses up milling untuk semua sudut kemiringan benda kerja.

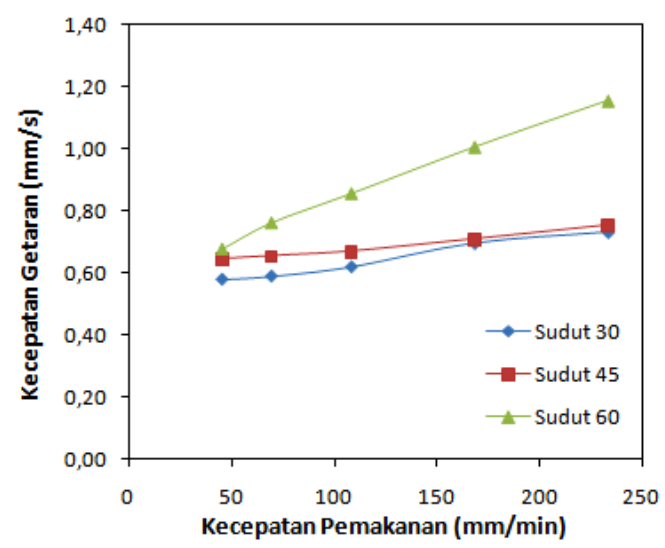

Gambar 8.

Grafikpengaruhkecepatanpemakananter hadapkecepatan getaran (upmilling) 


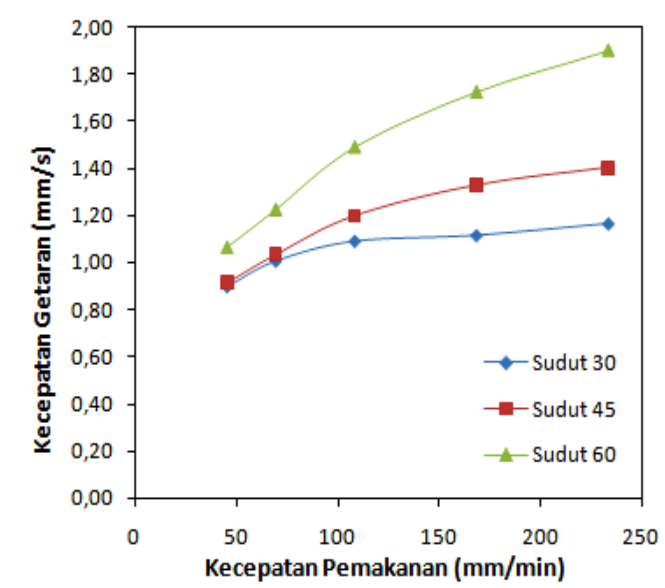

Gambar

9.

Grafikpengaruh kecepatanpemakananterhadap kcepatan getaran (down milling)

Gambar 8 dan gambar 9 memperlihatkan hubungan antara kecepatan pemakanan terhadap nilai kecepatan getaran pada proses frais dengan metode up millingdan metode down milling. Dari grafik terlihat jelas bahwa kecepatan getaran yang terjadi pada proses frais dengan variasi kecepatan pemakanan semakin besar seiring dengan semakin besarnya sudut kemiringan benda kerja yang digunakan. Hal ini terjadi karena pengaruh gaya statis yang terjadi pada ragum yang mencekam benda kerja. Posisi ragum yang ideal dalam mencekam benda kerja adalah posisi horizontal dengan sudut kemiringan $0^{\circ}$. Jika ragum dimiringkan dengan sudut kemiringan tertentu, maka ragum tersebut akan cenderung jatuh ke bawah ke posisi ideal untuk mencari kesetimbangan akibat adanya gaya gravitasi bumi, sehingga jika ragum yang mencekam benda kerja dimiringkan dengan sudut kemiringan yang sangat besar, maka gaya statis yang bekerja pada ragum akan semakin besar. Sehingga pada kasus ini, besarnya getaran yang terjadi dengan semakin besarnya sudut kemiringan benda kerja merupakan pengaruh dari besarnya gaya statis yang terjadi pada ragum.

Dari grafik juga terlihat jelas bahwa semakin besar nilai kecepatan pemakanan, maka semakin besar pula nilai kecepatan getaran yang terjadi baik pada proses up milling maupun pada proses down milling. Hal ini terjadi karena dengan semakin besar nilai kecepatan pemakanan yang digunakan pada proses frais menyebabkan gaya potong yang terjadi pada proses frais semakin besar, sehingga menimbulkan gesekan yang tinggi akibat dari kontak atau interaksi yang terjadi pada saat proses pemakanan dengan kecepatan pemakanan yang tinggi dan mengakibatkan getaran yang terjadi menjadi lebih tinggi.

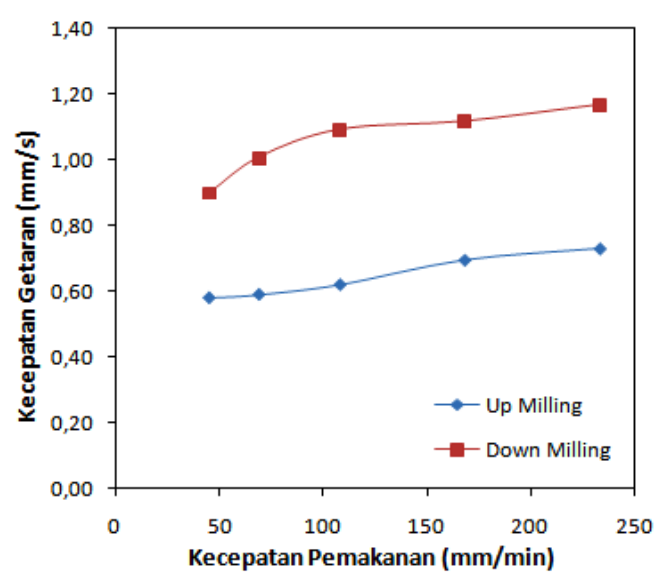

Gambar 10. Grafik pengaruhkecepatanpemakanan terhadap kecepatan getaran (sudut $30^{0}$ )

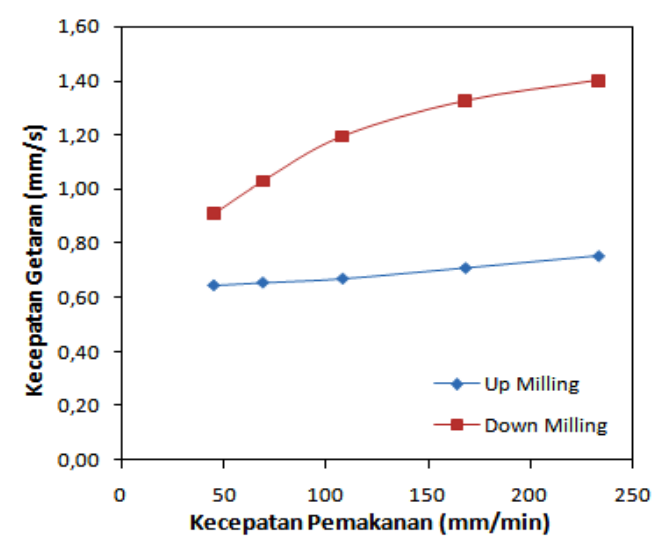

Gambar 11. Grafik pengaruh kecepatanpemakanan terhadap kecepatan getaran (sudut $45^{0}$ )

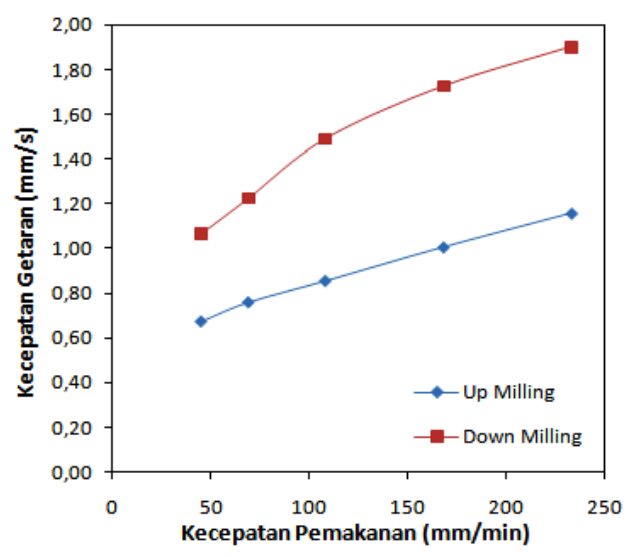

Gambar 12. Grafik pengaruh kecepatanpemakanan terhadap kecepatan getaran (sudut $60^{0}$ )

Gambar 10, gambar 11 dan gambar 12 memperlihatkan hubungan antara kecepatan pemakanan terhadap nilai kecepatan getaran pada proses frais dengan sudut kemiringan benda kerja 
$30^{\circ}, 45^{\circ}$ dan $60^{\circ}$. Dari grafik terlihat jelas bahwa nilai kecepatan getaran yang terjadi pada proses down milling lebih tinggi dibandingkan dengan nilai kecepatan getaran yang terjadi pada proses up milling. Hal ini disebabkan karena pada proses down milling cenderung menghasilkan pemakanan yang tebal karena putaran spindel searah dengan pergerakan meja. Hal ini mengakibatkan pemakanan yang terjadi selalu disaingi dengan laju pemakanan, sehingga menghasilkan geram yang lebih besar dan kasar. Selain itu pada proses down milling meja cenderung tertarik oleh cutter akibat dari putaran spindel yang yang searah dengan pergerakan meja.

\section{Perbandingan Antara Kemiringan Benda Kerja Dengan Kemiringan Spindel Terhadap Getaran Mesin Frais}

Pada proses frais dengan pemakanan menyudut, terdapat dua cara yang bisa digunakan yaitu dengan cara memiringkan spindel atau dengan cara memiringkan benda kerja. Pada penelitian sebelumnya [1], dilakukan penelitian tentang pengaruh kemiringan spindel dan kecepatan pemakanan benda kerja terhadap getaran mesin frais universal Knuth UFM 2. Hasil penelitian tersebut dapat dilihat pada tabel 2.

Tabel 2. Hasil pengukuran kemiringan spindel dan kecepatan pemakanan terhadap getaran mesin frais

\begin{tabular}{|c|c|c|c|c|c|c|c|c|c|c|}
\hline \multirow[b]{2}{*}{ No } & \multirow[b]{2}{*}{$\begin{array}{l}\boldsymbol{\theta} \\
\left({ }^{\mathbf{0}}\right)\end{array}$} & \multirow[b]{2}{*}{$\begin{array}{c}\mathrm{N} \\
(\mathbf{r p m})\end{array}$} & \multirow{2}{*}{$\begin{array}{c}\text { Vf } \\
(\mathbf{m} / \mathbf{m n t})\end{array}$} & \multirow[b]{2}{*}{$\begin{array}{l}\text { DOC } \\
(\mathrm{mm})\end{array}$} & \multicolumn{3}{|c|}{ Up Milling } & \multicolumn{3}{|c|}{ Down Milling } \\
\hline & & & & & $\begin{array}{c}\mathrm{V}_{1} \\
(\mathrm{~mm} / \mathrm{s})\end{array}$ & $\begin{array}{c}\mathrm{V}_{2} \\
(\mathrm{~mm} / \mathrm{s})\end{array}$ & $\begin{array}{c}\text { Vrata-rata } \\
(\mathrm{mm} / \mathrm{s})\end{array}$ & $\begin{array}{c}\mathrm{V}_{1} \\
(\mathrm{~mm} / \mathrm{s})\end{array}$ & $\begin{array}{c}\mathrm{V}_{2} \\
(\mathrm{~mm} / \mathrm{s})\end{array}$ & $\begin{array}{c}\text { Vrata-rata } \\
(\mathrm{mm} / \mathrm{s})\end{array}$ \\
\hline 1 & 30 & 388 & 45 & 0,50 & 0,20 & 0,23 & 0,22 & 0,36 & 0,37 & 0,37 \\
\hline 2 & 30 & 388 & 69 & 0,50 & 0,27 & 0,25 & 0,26 & 0,38 & 0,42 & 0,40 \\
\hline 3 & 30 & 388 & 108 & 0,50 & 0,29 & 0,28 & 0,29 & 0,40 & 0,43 & 0,42 \\
\hline 4 & 30 & 388 & 168 & 0,50 & 0,32 & 0,31 & 0,32 & 0,45 & 0,45 & 0,45 \\
\hline 5 & 30 & 388 & 233 & 0,50 & 0,36 & 0,33 & 0,35 & 0,51 & 0,47 & 0,49 \\
\hline \multirow[b]{2}{*}{ No } & \multirow[b]{2}{*}{$\begin{array}{l}\boldsymbol{\theta} \\
\left({ }^{\mathbf{0}}\right)\end{array}$} & \multirow[b]{2}{*}{$\begin{array}{c}\mathrm{N} \\
(\mathbf{r p m})\end{array}$} & \multirow[b]{2}{*}{$\begin{array}{c}\text { Vf } \\
(\mathbf{m} / \mathbf{m n t})\end{array}$} & \multirow[b]{2}{*}{$\begin{array}{l}\text { DOC } \\
(\mathrm{mm})\end{array}$} & \multicolumn{3}{|c|}{ Up Milling } & \multicolumn{3}{|c|}{ Down Milling } \\
\hline & & & & & $\begin{array}{c}\mathbf{V}_{1} \\
(\mathrm{~mm} / \mathbf{s})\end{array}$ & $\begin{array}{c}\mathbf{V}_{2} \\
(\mathrm{~mm} / \mathbf{s})\end{array}$ & $\begin{array}{c}\text { Vrata-rata } \\
(\mathbf{m m} / \mathbf{s})\end{array}$ & $\begin{array}{c}\mathbf{V}_{1} \\
(\mathbf{m m} / \mathbf{s}) \\
\end{array}$ & $\begin{array}{c}\mathbf{V}_{2} \\
(\mathbf{m m} / \mathbf{s})\end{array}$ & $\begin{array}{c}\text { Vrata-rata } \\
(\mathrm{mm} / \mathrm{s})\end{array}$ \\
\hline 1 & 45 & 388 & 45 & 0,50 & 0,26 & 0,26 & 0,26 & 0,38 & 0,40 & 0,39 \\
\hline 2 & 45 & 388 & 69 & 0,50 & 0,28 & 0,30 & 0,29 & 0,40 & 0,41 & 0,41 \\
\hline 3 & 45 & 388 & 108 & 0,50 & 0,29 & 0,32 & 0,31 & 0,42 & 0,43 & 0,43 \\
\hline 4 & 45 & 388 & 168 & 0,50 & 0,33 & 0,35 & 0,34 & 0,46 & 0,45 & 0,46 \\
\hline 5 & 45 & 388 & 233 & 0,50 & 0,35 & 0,35 & 0,35 & 0,50 & 0,49 & 0,50 \\
\hline \multirow[b]{2}{*}{ No } & \multirow[b]{2}{*}{$\begin{array}{l}\boldsymbol{\theta} \\
\left({ }^{\mathbf{0}}\right)\end{array}$} & \multirow[b]{2}{*}{$\begin{array}{c}\mathrm{N} \\
(\mathbf{r p m})\end{array}$} & \multirow[b]{2}{*}{$\begin{array}{c}\text { Vf } \\
(\mathbf{m} / \mathbf{m n t})\end{array}$} & \multirow[b]{2}{*}{$\begin{array}{l}\text { DOC } \\
(\mathrm{mm})\end{array}$} & \multicolumn{3}{|c|}{ Up Milling } & \multicolumn{3}{|c|}{ Down Milling } \\
\hline & & & & & $\begin{array}{c}\mathbf{V}_{1} \\
(\mathbf{m m} / \mathbf{s})\end{array}$ & $\begin{array}{c}\mathbf{V}_{\mathbf{2}} \\
(\mathbf{m m} / \mathbf{s})\end{array}$ & $\begin{array}{c}\text { Vrata-rata } \\
(\mathbf{m m} / \mathbf{s})\end{array}$ & $\begin{array}{c}\mathbf{V}_{1} \\
(\mathbf{m m} / \mathbf{s})\end{array}$ & $\begin{array}{c}\mathbf{V}_{2} \\
(\mathbf{m m} / \mathbf{s})\end{array}$ & $\begin{array}{c}\text { Vrata-rata } \\
(\mathbf{m m} / \mathbf{s})\end{array}$ \\
\hline 1 & 60 & 388 & 45 & 0,50 & 0,28 & 0,27 & 0,28 & 0,41 & 0,43 & 0,42 \\
\hline 2 & 60 & 388 & 69 & 0,50 & 0,33 & 0,31 & 0,32 & 0,48 & 0,47 & 0,48 \\
\hline 3 & 60 & 388 & 108 & 0,50 & 0,41 & 0,41 & 0,41 & 0,51 & 0,53 & 0,52 \\
\hline 4 & 60 & 388 & 168 & 0,50 & 0,47 & 0,46 & 0,47 & 0,65 & 0,63 & 0,64 \\
\hline 5 & 60 & 388 & 233 & 0,50 & 0,58 & 0,59 & 0,59 & 0,75 & 0,77 & 0,76 \\
\hline
\end{tabular}

Sumber : Romiyadi, dkk (2014)

Keterangan :

- $\Theta=$ Sudut Kemiringan Benda Kerja

- $\mathrm{N} \quad=$ Kecepatan Putaran Spindel

- Vf = Kecepatan Pemakanan

Jika dibandingkan antara pengaruh kemiringan benda kerja (tabel 1) dan pengaruh kemiringan spindel (tabel 2) terhadap getaran yang terjadi pada mesin frais, maka terlihat jelas getaran yang terjadi pada proses frais dengan kemiringan benda kerja lebih besar dibandingkan getaran yang terjadi pada proses frais dengan kemiringan spindel. Gambar 13, 14 dan 15 memperlihatkan perbandingan antara kemiringan benda kerja dengan kemiringan spindel terhadap getran mesin frais pada sudut kemiringan $30^{\circ}, 45^{\circ}$ dan $60^{\circ}$.
- $\quad$ DOC $=$ Kedalaman Potong

- $\mathrm{V}_{1}=$ Kecepatan Getaran Pengujian ke 1

- $\mathrm{V}_{2}=$ Kecepatan GetaranPengujian ke 2 


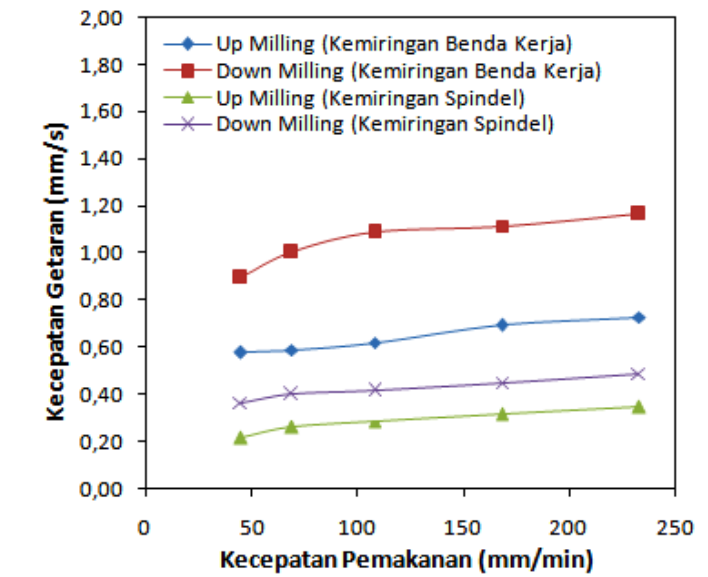

Gambar 13. Grafik perbandingan kemiringanbendakerja dan kemiringan spindel terhadap getaran mesin frais (sudut $30^{\circ}$ )

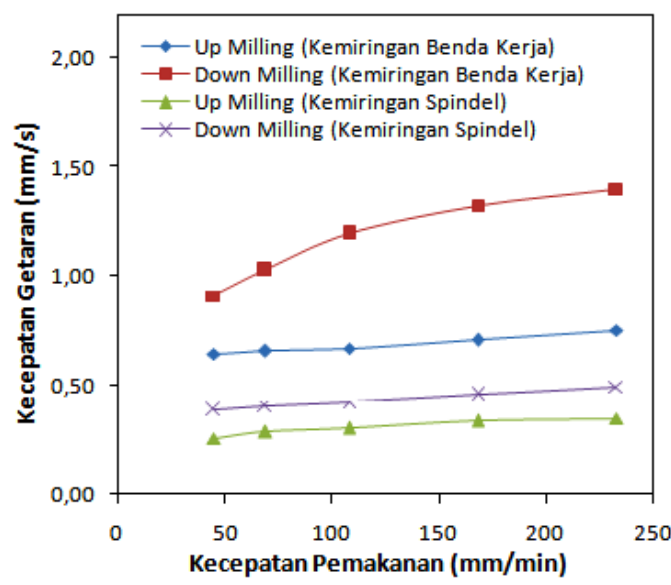

Gambar 14. Grafik

perbandingan kemiringanbenda kerja dan kemiringan spindel terhadap getaran mesin frais (sudut $45^{\circ}$ )

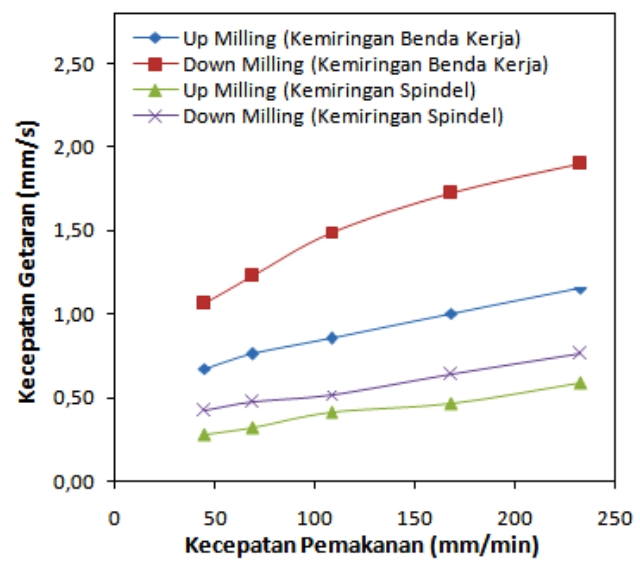

Gambar 15. Grafik perbandingan kemiringanbenda kerja dan kemiringan spindel terhadap getaran mesin frais (sudut $60^{\circ}$ )

Dari gambar 13, 14 dan 15 terlihat jelas bahwa getaran yang terjadi pada proses frais dengan kemiringan benda kerja lebih besar dibandingkan dengan getaran yang terjadi pada proses frais dengan kemiringan spindel baik pada proses up milling maupun pada proses down milling. Hal ini disebabkan karena kekakuan spindelpada proses frais dengan kemiringan spindel lebih tinggi dibandingkan dengan kekakuan ragum pada proses frais dengan kemiringan benda kerja. Sehingga getaran mesin frais yang terjadi pada proses frais dengan kemiringan benda kerja lebih besar jika dibandingkan dengan getaran yang terjadi pada proses frais dengan kemiringan spindel.

Dengan demikian, dari penelitian ini dan daripenelitian yang dilakukan sebelumnya [1], dapat disimpulkan bahwa pada proses frais pemakanan menyudut dengan kemiringan benda kerja akan menghasilkan getaran mesin frais yang lebih besar dibandingkan dengan getaran yang terjadi pada proses frais dengan kemiringan spindel. Oleh karena itu, penulis merekomendasikan kepada operator mesin frais untuk menggunakan cara memiringkan spindel dari pada menggunakan cara memiringkan benda kerja jika mengoperasikan mesin frais pada proses frais dengan pemakanan menyudut karena akan menghasilkan getaran yang lebih kecil.

\section{KESIMPULAN}

Hasil penelitian menunjukkan bahwa semakin besar kemiringan benda kerja, semakin besar pula getaran mesin frais yang terjadi baik pada proses $u p$ milling maupun pada proses down milling. Begitu pula dengan pengaruh perubahan kecepatanpemakanan terhadap getaran mesin frais. Hasil penelitian menunjukkan bahwa pada kemiringan benda kerja $30^{\circ}, 45^{\circ}$ maupun $60^{\circ}$, perubahan kecepatan pemakanan akan memberikan pengaruh positif terhadap getaran mesin frais. Hasil penelitian juga menunjukkan bahwa getaran mesin frais yang terjadi pada proses down milling lebih tinggi dibandingan dengan getaran pada proses up milling untuk semua kemiringan spindel.

\section{DAFTAR PUSTAKA}

[1] Romiyadi., Azriadi, E. 2014. Pengaruh Kemiringan Spindel dan Kecepatan Pemakanan Kecepatan Pemakanan Terhadap Getaran Mesin Perkakas Mesin Frais Universal Knuth UFM 2. Jurnal Teknobiologi. 5(1): 31-36

[2] Romiyadi., Azriadi, E. 2012. Pengaruh Parameter Kecepatan Pemakanan Terhadap 
Getaran Mesin Perkakas Pada Proses Up Milling Dan Down [3] Milling Menggunakan Mesin Frais Universal Knuth UFM 2. Proseding Seminar Nasional Rekayasa Teknologi Industri dan Informasi ke 7. 15 Desember 2012. Yogyakarta.

[4] Muas, M. 2008. Pengaruh Getaran Pemesinan Terhadap Kekasaran Permukaan Pada Mesin VMC-200. Jurnal Sinergi. 6(1):33-32

[5] Hendra. 2006. Pengukuran Sinyal Getaran Pada Mesin Bubut Gallic 16N Dengan Menggunakan Multychannel Spectrum Analyzer. Jurnal Teknik Mesin. 3(2):99-105

[6] Zulhendri, Kiswanto, G., Yazmendra, R. 2007. Pengaruh Tipe pahat dan Arah Pemakanan Permukaan Berkontur Pada Pemesinan Milling Awal Dan akhir Terhadap Kekasaran Permukaan. Jurnal Teknik Mesin. 4(1):15-22

[7] Hernadewita, Hendra, Herman. 2006 Analisis Pengaruh Kondisi Pemotongan Benda Kerja (Panjang penjuluran Terhadap Kekasaran Permukaan Pada Mesin Bubut Gallic 16N. Jurnal Teknik Mesin. 3(1):55-61

[8] Kalpakjian S, Steven R. Schmid. 2006. Manufacturing, Engineering And Technology. Edisi 5. Pearson Education, Inc.

[9] Phase II Machine Tools, Inc. 2008. DigitalVibration Tester Model No. DVM 1000 : Operation Manual. New Jersey : Phase II Machine \& Tool, Inc. 